\title{
Dual stable isotope abundances unravel trophic position of estuarine nematodes
}

\author{
Tom Moens* ${ }^{\int}$, Steven Bouillon ${ }^{\dagger}$ and Fabiane Gallucci* ${ }^{\ddagger}$ \\ *Ghent University, Department of Biology, Marine Biology Section, Krijgslaan 281/S8, B-9000 Gent, Belgium. \\ ${ }^{\dagger}$ Vrije Universiteit Brussel, Department of Analytical and Environmental Chemistry, Mangrove Management Group, \\ Pleinlaan 2, 1050 Brussels, Belgium. ${ }^{\ddagger}$ Universidade do Sul de SantaCatarina, Laboratório de Ciências Marinhas, \\ Av. Colombo Sales 84, Laguna, SC, 88790-000, Brazil. `Corresponding author, e-mail: tom.moens@UGent.be
}

\begin{abstract}
The role and quantitative importance of free-living nematodes in marine and estuarine soft sediments remain enigmatic for lack of empirical evidence on the feeding habits and trophic position of most nematode species. Here we use natural abundances of carbon and nitrogen stable isotopes of some abundant nematode species/genera from estuarine intertidal sediments to assess their trophic level and major food sources. In all stations, $\delta^{15} \mathrm{~N}$ of different dominant nematode species/genera spanned a range of 3.6 to $6.3 \mathrm{ppt}$, indicating that at least two trophic levels were represented. The large nematodes Enoplus brevis, Enoploides longispiculosus and Adoncholaimus fuscus consistently had high $\delta^{15} \mathrm{~N}$, in line with mouth-morphology based predictions and empirical evidence on their predacious feeding modes. Daptonema sp., Metachromadora remanei, Praeacanthonchus punctatus and 'Chromadoridae' (dominated by Ptycholaimellus ponticus) had comparatively lower $\delta^{15} \mathrm{~N}$, and $\delta^{13} \mathrm{C}$ suggesting that microphytobenthos (MPB) is their major carbon source, although freshly sedimented particulate organic matter may also contribute to their nutrition in silty sediments. The trophic position of Sphaerolaimus sp., a genus with documented predacious feeding mode, was ambiguous. Ascolaimus elongatus had $\delta^{15} \mathrm{~N}$ signatures indicating a predacious ecology, which is at variance with expectations from existing feeding type classifications. Our study shows that - despite limitations imposed by the biomass requirements for EA-IRMS (elemental analyser - isotope ratio mass spectrometry) - natural isotope abundances of carbon and nitrogen are powerful tools to unravel trophic structure within nematode communities. At the same time, the prominence of different trophic levels results in a large span of $\delta^{15} \mathrm{~N}$, largely invalidating the use of nitrogen isotope abundances to assess food sources and trophic level of whole nematode communities.
\end{abstract}

\section{INTRODUCTION}

Nematodes are the most abundant metazoans in estuarine and marine soft sediments, with densities typically in the order of $10^{6}$ ind $\mathrm{m}^{-2}$ and corresponding biomass of 0.1 to $10 \mathrm{~g} \mathrm{C} \mathrm{m}^{-2}$. Although their biomass is generally low, their high abundance and high metabolic and reproductive rates render them potentially important in benthic fluxes of carbon and nutrients (Kuipers et al., 1981; Coull, 1999).

Assessment of the roles of nematodes in benthic carbon flows remains problematic due to the paucity of both qualitative and quantitative information on their trophic ecology. Nematode communities are often regarded as grazers of microalgae and bacteria, but predation on both proto- and metazoan heterotrophs is also a potentially important feeding strategy (Moens \& Vincx, 1997). Interpretation of nematode feeding behaviour is generally based on stoma and pharyngeal morphology (Wieser, 1953). A variety of species, then, have their mouth equipped with teeth, mandibles, and/or other sclerotized structures which may serve a predacious feeding mode. However, the absence of empirical evidence that documents trophic level of different nematode species/genera/ trophic types hampers proper assessment of (meio) benthic foodweb structure.
Stable isotopes are powerful tools in foodweb research. While carbon isotopic signatures of consumer and resource are typically very similar, nitrogen isotope ratios show a measurable offset between different trophic levels (Vander Zanden \& Rasmussen, 2001; Post, 2002). Hence, dual stable isotope signatures may reveal information on both resources and trophic level of consumers, provided sufficient biomass is available for analysis. This may be problematic when working with very small animals like nematodes, because the configuration of most commercial EA-IRMS (elemental analyser - isotope ratio mass spectrometry) still requires at least $5 \mu \mathrm{g} \mathrm{C}$ or $\mathrm{N}$, which for $\mathrm{N}$ often corresponds to several hundred nematodes. Hence, dual stable isotope ratios of meiobenthos have hitherto only been reported on a community level (e.g. Couch, 1989; Riera et al., 1996, 1999; Riera \& Hubas, 2003), with the exception of a single study involving three harpacticoid copepod and two nematode species (Carman \& Fry, 2002). There are, for instance, at present no stable nitrogen isotope data in support of the supposedly predatory ecology of any marine or estuarine nematode. The aim of this research was therefore to document trophic levels of some abundant estuarine tidal flat nematodes at the genus or species level using dual stable isotope signatures, focusing specifically on species with presumed predatory or diatom grazer ecology. 


\section{MATERIALS AND METHODS}

\section{Study sites}

Samples were collected in May 2004 at four stations adjacent to and in the Paulina saltmarsh, in the polyhaline reach (average salinity between 24 and 32) of the Schelde estuary (south-west Netherlands) (Figure 1). Stations 1, 2 and 3 were located on the unvegetated tidal flat bordering the marsh upstream and correspond to stations 11, 5 and 2, respectively, in Gallucci et al. (in press); Station 4 was located at the edge of a gully within the saltmarsh and conforms to station PS A in Moens et al. (2002). These four stations differed in sediment granulometry and organic matter content (Table 1). In each station, several nematode species occurred in numbers and biomass

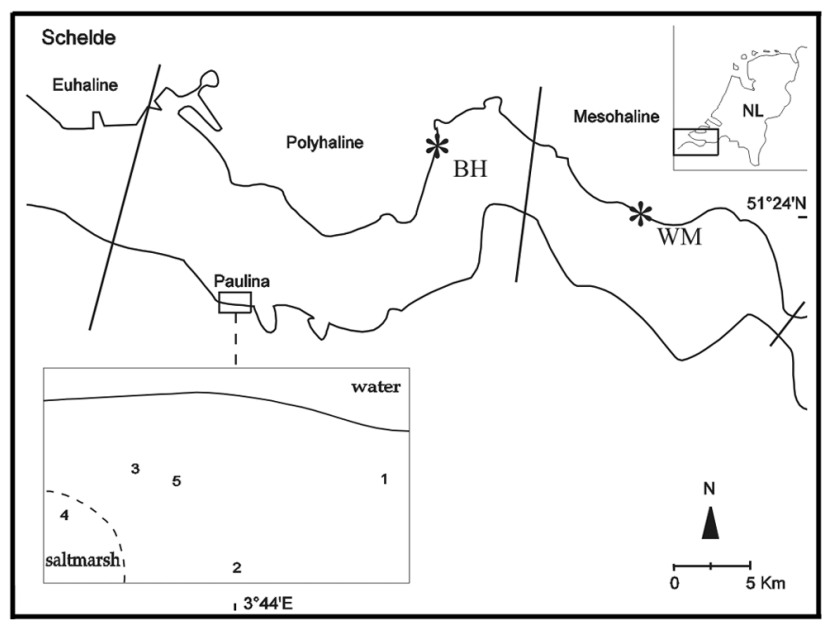

Figure 1. Map of the Schelde estuary, south-west Netherlands (NL), with the location of the Paulina intertidal flat and the positions of the sampling stations. BH, Biezelingse Ham; WM, Waarde marsh (see Table 2).

Table 1. Summary of sediment characteristics and nematode densities (total nematodes and some supposedly predacious species) in the upper $2 \mathrm{~cm}$ of our sampling stations at Paulina. Nematode data are means \pm 1 SD of three (Stations 1-3) or four (Station 4) replicates.

\begin{tabular}{lcccc}
\hline & \multicolumn{4}{c}{ Station } \\
\cline { 2 - 5 } & 1 & 2 & 3 & 4 \\
& & & & \\
\hline Sediment & & & \\
Mean grain size $(\mu \mathrm{m})$ & 244 & 201 & 50 & 93 \\
Silt (\%) & 0 & 4 & 57 & 29 \\
Organic carbon (\%) & 0.06 & 0.09 & 0.51 & 1.17 \\
Total nitrogen (\%) & 0.007 & 0.01 & 0.05 & 0.20 \\
Nematodes (ind 10 cm & -2 & & & \\
Total density & $400 \pm 147$ & $1202 \pm 545$ & $1825 \pm 813$ & $6450 \pm 18.45$ \\
Adoncholaimus fuscus & $1 \pm 0.6$ & $79 \pm 28$ & $11 \pm 17$ & $13 \pm 9$ \\
Enoploides & $101 \pm 36$ & $187 \pm 51$ & $1 \pm 1.1$ & $3 \pm 2.1$ \\
$\quad$ longispiculosus & & & & \\
Enoplus brevis & 0 & $6 \pm 7.5$ & $11 \pm 5$ & $23 \pm 14$ \\
Sphaerolaimus spp. & 0 & $4 \pm 5$ & $8 \pm 5$ & $41 \pm 19$ \\
\hline
\end{tabular}

sufficient for dual isotope analysis (see below); some species were sufficiently abundant in more than one station. A preliminary sampling in November 2003 at Sites 1 and 2 served to assess variability and requirements for biomass and number of individuals per analysis.

\section{Sampling}

The upper $2 \mathrm{~cm}$ of the sediment were sampled nonquantitatively at low tide by scraping the sediment surface off with a spoon. This material was then transferred to the laboratory, and stored at $4^{\circ} \mathrm{C}$ until sorting. Sorting was done within three days from the sampling date.

Nematodes were extracted from sediment by vigorous shaking under a jet of freshwater (which temporarily 'anaesthetizes' the nematodes, thus facilitating their release from the sediment), followed by decantation over a $53-\mu \mathrm{m}$ mesh size sieve. They were then collected in filtered habitat water. This procedure was repeated eight times, and yielded fairly clean suspensions of meiobenthos for samples from the sandy Stations 1 and 2, while more silt and detritus were retained in the silty samples from Stations 3 and 4.

Microphytobenthos was isolated from Stations 2 and 3 and from an additional Paulina Station (5) in February 2005, after migration through lens tissue and onto cover glasses. This yielded fairly clean, diatom-dominated biofilms which were scraped off from the cover glasses, freeze-dried and acidified with dilute $\mathrm{HCl}$. Sediment samples for isotopic analysis from all stations were also obtained in February 2005. They were dried, ground and-for measurements of carbon isotopic ratios onlypretreated with dilute $\mathrm{HCl}$ to remove carbonates.

\section{Natural stable carbon and nitrogen isotope signatures of nematodes}

Nematodes were handpicked with a fine needle, rinsed once in sterile artificial seawater to remove adhering particles, and finally transferred to a drop of Milli-Q water in $2.5 \times 6 \mathrm{~mm}$ aluminium cups (Elemental Microanalysis Ltd). Pretreatment of the aluminium cups for $4 \mathrm{~h}$ at $550^{\circ} \mathrm{C}$ typically yielded undetectably low background values for carbon. Background values for nitrogen were more variable, ranging from undectable to $\leqslant 1 \mu \mathrm{g} \mathrm{N}$ (the latter applying to a single blank), yet usually $\approx 0.5 \mu \mathrm{g} \mathrm{N}$. Nematodes were not starved prior to sorting, hence their isotopic signatures reflect both assimilated and ingested matter. While it may be advisory to analyse organisms with empty guts, starvation in nematodes often strongly delays defaecation and is therefore not always very efficient (T. Moens, unpublished observations).

Sorting was restricted to nematode species/genera which were easily recognizable under a stereomicroscope and which were available in sufficient biomass, i.e. $\geqslant 25 \mu \mathrm{g} \mathrm{C}$, as estimated from measurements of length and width, yielding nematode wet weight, and from a conservative estimate of carbon at $10 \%$ of nematode wet weight (Somerfield et al., 2005). There is very little information on nitrogen content in nematodes; assuming an average C/N-ratio of 5.9 (Ferris et al., 1997), our samples always contained $>4 \mu \mathrm{gN}$, and usually in-between 5 and $15 \mu \mathrm{g} \mathrm{N}$. Replicates were not obtained systematically for 

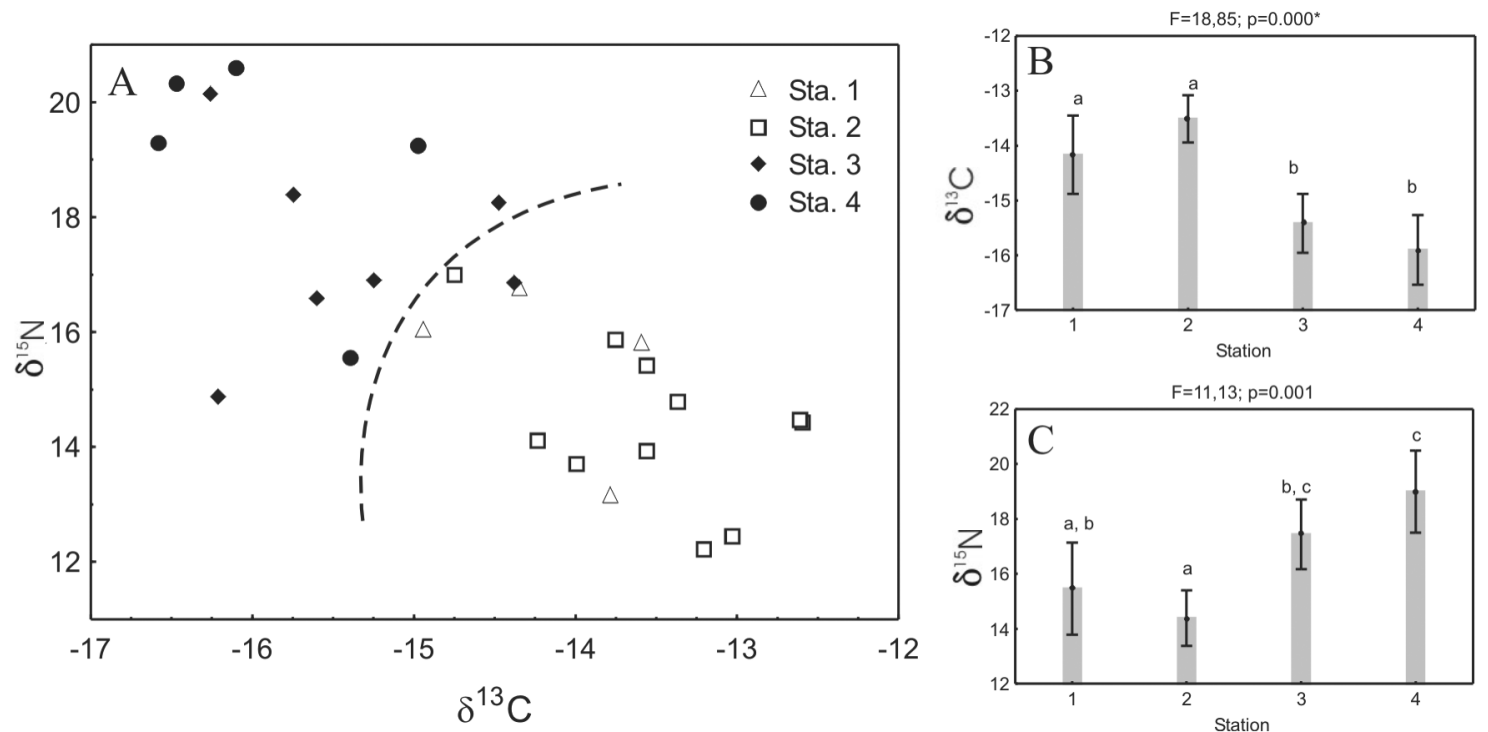

Figure 2. (A) $\delta^{13} \mathrm{C}$ vs $\delta^{15} \mathrm{~N}$ for nematode species/genera at the Paulina tidal flat in May 2004 (Stations 1 to 4 combined); all data points are single measurements of single species/genera; (B) nematode $\delta^{13} \mathrm{C}$ per station; and $(\mathrm{C})$ nematode $\delta^{15} \mathrm{~N}$ per station. $($ mean \pm 1 STD $)$. The values in $(B)$ and $(\mathrm{C})$ are means \pm 1 STD of all the data on single species/genera grouped per station.

Station 1

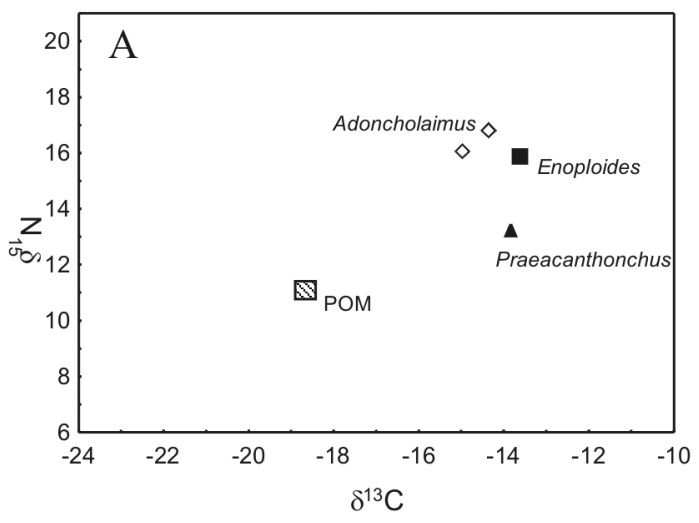

Station 3

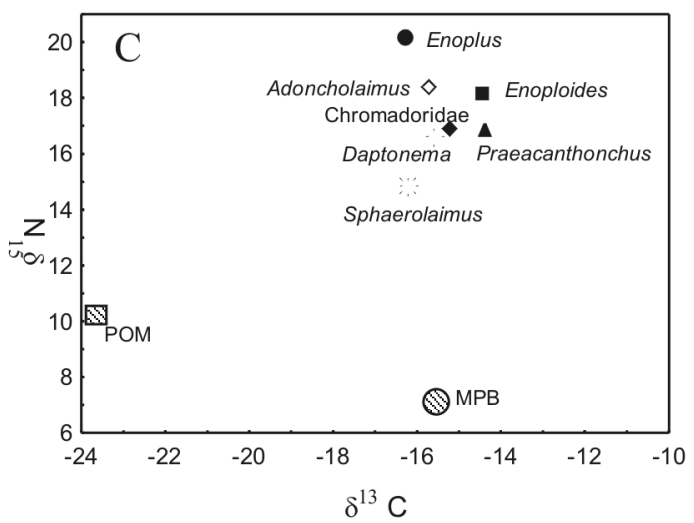

Station 2

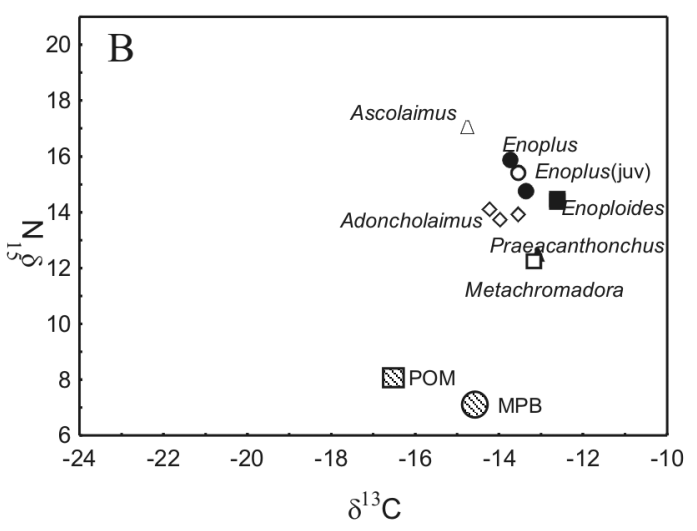

Station 4

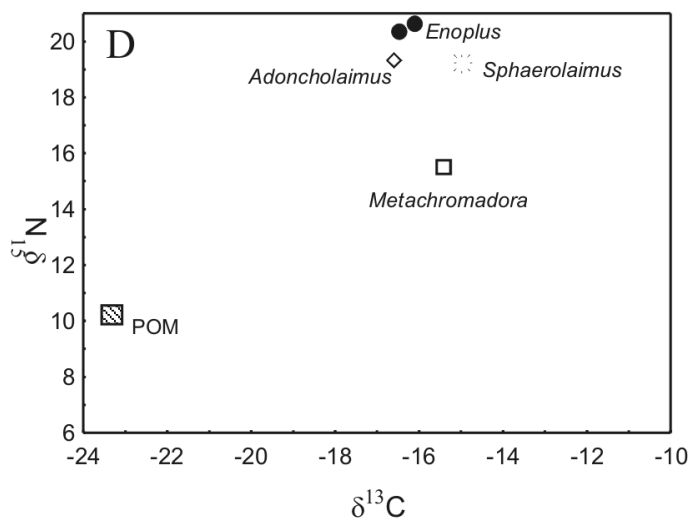

Figure 3. The $\delta^{13} \mathrm{C}$ vs $\delta^{15} \mathrm{~N}$ for each nematode species/genus at Stations 1 to 4 at the Paulina tidal flat in May 2004. Where available, isotopic signatures of microphytobenthos (MPB) and particulate organic matter (POM) are also shown.

lack of sufficient biomass; where possible, 2-4 replicate samples were analysed for the presumed predators Enoplus brevis, Enoploides longispiculosus and Adoncholaimus fuscus. Aluminium cups containing nematodes were oven dried, closed and stored in screw-cap glass tubes until analysis.

Isotopic analyses of nematodes, MPB and sediment organic matter used a ThermoFinnigan Flash 1112 
Table 2. Stable carbon and nitrogen isotope signatures (ppt, means \pm 1 SD) of particulate organic matter (POM) and microphytobenthos (MPB) of intertidal areas in the polyhaline reach of the Schelde estuary (exception made for location WM, which is in the mesohaline part).

\begin{tabular}{|c|c|c|c|c|c|c|c|}
\hline Location & $\operatorname{POM} \delta^{13} \mathrm{C}$ & $\operatorname{POM} \delta^{15} \mathrm{~N}$ & $\operatorname{MPB} \delta^{13} \mathrm{C}$ & $\operatorname{MPB} \delta^{15} \mathrm{~N}$ & Spartina $\delta^{13} \mathrm{C}$ & Spartina $\delta^{15} \mathrm{~N}$ & Sampling date \\
\hline $1^{\mathrm{a}}$ & $-19.5 \pm 0.1(2)$ & $11.3 \pm 0.2(2)$ & - & - & & & Feb 2005 \\
\hline $2^{\mathrm{a}}$ & $-16.7 \pm 1.2(2)$ & $9.0 \pm 1.5(2)$ & $-14.5 \pm 0.6(3)$ & $7.7 \pm 0.2(3)$ & & & Feb 2005 \\
\hline $3^{\mathrm{a}}$ & $-23.7 \pm 1.0(3)$ & $10.6 \pm 0.9(3)$ & $-15.7 \pm 0.9(3)$ & $7.4 \pm 0.2(3)$ & & & Feb 2005 \\
\hline $4^{\mathrm{a}}$ & $-23.2 \pm 0.1$ & $10.8 \pm 1.0(3)$ & - & - & & & Feb 2005 \\
\hline $5^{\mathrm{a}}$ & $-21.8 \pm 0.3(2)$ & $10.2 \pm 0.13(2)$ & $-14.3 \pm 0.3(3)$ & $8.3 \pm 0.8(3)$ & & & Feb 2005 \\
\hline $\begin{array}{l}\text { Waarde } \\
\text { marsh }^{\mathrm{e}, \mathrm{f}}\end{array}$ & $\begin{array}{l}-22.0(0-5 \mathrm{~cm}) \\
-23.5(5-10 \mathrm{~cm})\end{array}$ & & & & $\begin{array}{l}-12.2 \text { (live, } \\
\text { above ground) } \\
-12.5 \text { (live, } \\
\text { below ground) }\end{array}$ & $\begin{array}{l}16.0 \pm 3.07(6) \\
\text { (green leaves) }\end{array}$ & $\begin{array}{c}\text { Aug } 1994^{\mathrm{e}} \\
\text { Aug-Sep } 2000^{\mathrm{f}}\end{array}$ \\
\hline $\begin{array}{l}\text { Waarde } \\
\text { marsh }^{\mathrm{e}, \mathrm{f}}\end{array}$ & & & & & -13.1 (litter) & $\begin{array}{c}15.0 \pm 0.5(18) \\
\text { (above ground } \\
\text { live) }\end{array}$ & $\begin{array}{c}\text { Aug } 1994^{\mathrm{e}} \\
\text { Aug-Sep } 2000^{\mathrm{f}}\end{array}$ \\
\hline $\mathrm{BH}^{\mathrm{b}}$ & - & $8.6 \pm 0.2(8)$ & - & $17.7 \pm 1.4(4)$ & & & Jan-Feb 1998 \\
\hline $\mathrm{BH}^{\mathrm{b}}$ & - & $\begin{array}{l}8.1 \pm 0.1(2) \\
(\text { SPOM })\end{array}$ & - & - & & & Jan-Feb 1998 \\
\hline $\mathrm{LE}^{\mathrm{c}, \mathrm{d}}$ & -21.0 to -24.0 & 8.0 to 13.5 & - & - & & & \\
\hline $\mathrm{LE}^{\mathrm{c}, \mathrm{d}}$ & $\begin{array}{c}-20.0 \text { to }-24.0 \\
(\mathrm{SPOM})\end{array}$ & $\begin{array}{l}7.0 \text { to } 15.0 \\
(\text { SPOM })\end{array}$ & - & - & & & \\
\hline
\end{tabular}

Unless otherwise indicated (as SPOM), POM refers to sediment organic matter. SPOM, suspended particulate organic matter. Locations 1-5 are the Paulina stations of the present study (see Figure 1). BH, Biezelingse Ham; LE, Lower Estuary (compilation of different sample locations). Figures between brackets refer to the number of replicate samples. Sources: a, the present study; b, Riera et al. (2000); c, Nieuwenhuize \& Middelburg (1998); d, Rossi et al. (2004); e, Middelburg et al. (1997) (only $\delta^{13} \mathrm{C}$ data); f, T. Bouma (personal communication, raw $\delta^{15} \mathrm{~N}$ data used in Bouma et al. (2002)).

elemental analyser coupled on-line via a Conflo III interface to a ThermoFinnigan Delta Plus XL mass spectrometer, with analytical reproducibility typically at $\pm 0.15 \mathrm{ppt}$ for both $\delta^{13} \mathrm{C}$ and $\delta^{15} \mathrm{~N}$. Stable isotope ratios are expressed relative to the conventional standards (Vienna PDB for carbon and atmospheric $\mathrm{N}_{2}$ for nitrogen) in units of parts per thousand, according to the formula: $\delta^{13} \mathrm{C}$ or $\delta^{15} \mathrm{~N}=\left[\left(\mathrm{R}_{\text {sample }} / \mathrm{R}_{\text {standard }}\right)-1\right] \times 10^{3} \mathrm{ppt}$, where $\mathrm{R}$ is the ratio of ${ }^{13} \mathrm{C} /{ }^{12} \mathrm{C}$ or ${ }^{15} \mathrm{~N} /{ }^{14} \mathrm{~N}$.

\section{RESULTS}

The $\delta^{13} \mathrm{C}$ of nematodes showed significant variability between sites but little variability within sites (Figure 2). The $\delta^{15} \mathrm{~N}$ of nematodes exhibited even more pronounced inter-site differences, values in silty sediment typically exceeding those in the sandier sediments by 3-5 ppt (Figure 2). This trend is confirmed when looking only at the values for Adoncholaimus fuscus (found in all four stations) and Enoplus brevis (found in three stations). In contrast to $\delta^{13} \mathrm{C}$ signatures, $\delta^{15} \mathrm{~N}$ differed substantially among different nematode genera within sites, with a range of 3.6 (Station 1) to $6.3 \mathrm{ppt}$ (Station 3) between the lowest and highest values (Figure 3). Enoplus brevis, Enoploides longispiculosus and Adoncholaimus fuscus consistently had comparatively high $\delta^{15} \mathrm{~N}$, and so did Ascolaimus elongatus in the single station where it was obtained in sufficient quantity for dual isotope analysis. By contrast, Praeacanthonchus punctatus, Metachromadora remanei, Daptonema sp. and Chromadoridae had $\delta^{15} \mathrm{~N}$ in the lower end of recorded values (unfortunately, only the first two species were obtained from more than one station), while the position of Sphaerolaimus sp. was ambiguous (Figure 3).

\section{DISCUSSION}

\section{Carbon sources of estuarine intertidal nematodes}

Food sources for the benthos in tidal flats of the Schelde Estuary are fairly well-documented, although their isotopic signatures are typically better constrained for carbon than nitrogen (Middelburg et al., 1997; Middelburg \& Nieuwenhuize, 1998; Hellings et al., 1999; Herman et al., 2000; Riera et al., 2000; Moens et al., 2002). A summary of stable isotopic data of prominent food sources in this part of the estuary is given in Table 2. In addition to the in situ production by microphytobenthos (mainly diatoms), tidal flats receive significant inputs from suspended particulate organic matter (SPOM), which in this part of the estuary is reflected in sedimentary organic matter (SOM) with carbon and nitrogen isotope signatures very close to those of SPOM (Middelburg \& Nieuwenhuize, 1998; Herman et al., 2000; Moens et al., 2002). Sea grasses are absent from the estuary, while inputs of macroalgae and terrestrial vascular plants are only of very local significance. Within the Paulina saltmarsh, inputs of local Spartina anglica production are significant, yet the carbon isotopic signatures of SOM show that inputs of SPOM are highly important (Moens et al., 2002). Indeed, the small marshes along this estuary are typically mineral marshes where trapping of allochthonous organic matter heavily depletes SOM $\delta^{13} \mathrm{C}$ compared to Spartina-derived organic matter (Middelburg et al., 1997).

The generally depleted carbon signals of nematodes in the two silty stations compared to the sandier ones (Figure 2) reflect a higher availability of labile watercolumn derived particulate organic matter in the former, and are in line with previous results from this and another 
intertidal flat in the Schelde estuary (Moens et al., 2002). These data show that microphytobenthos is the main carbon source for nematode communities in sandy sediments, while both microphytobenthos and sedimented phytoplankton provide carbon to the meiobenthos in siltier stations. This corroborates the proposed importance of microphytobenthos as a principal carbon source for tidal flat nematodes (Riera et al., 1996; Middelburg et al., 2000; Moens et al., 2002), but not the suggestion that nematode communities in salt marshes additionally draw upon more refractory, vascular plant-derived organic matter, which is isotopically heavier (Couch, 1989; Riera et al., 1999; Carman \& Fry, 2002).

The $\delta^{15} \mathrm{~N}$ of marine and riverine endmember particulate organic nitrogen (PON) for the Schelde estuary is typically 8-10 ppt (Middelburg \& Nieuwenhuize, 1998). Estuarine PON, by contrast, has more variable and often enriched $\delta^{15} \mathrm{~N}$ as a result of assimilation of heavy residual $\mathrm{NH}_{4}{ }^{+}$by microalgae and bacteria (Mariotti et al., 1984; Middelburg \& Nieuwenhuize, 1998; Riera et al., 2000). The heavy $\mathrm{NH}_{4}{ }^{+}$signal in turn probably results from nitrification and/or autotrophic fractionation during assimilation (Mariotti et al., 1984; Middelburg \& Nieuwenhuize, 1998). The clear separation of silty and sandy stations in this study - with consistently heavier N-signatures in consumers of the silty stations (Figure 2)-is unlikely to reflect differences in the relative availability of phytoplankton and microphytobenthos, because phytoplankton $\delta^{15} \mathrm{~N}$ is lower than or similar to microphytobenthos $\delta^{15} \mathrm{~N}$ (Riera et al., 2000). The SOM $\delta^{15} \mathrm{~N}$ over our study sites indeed did not differ (Table 2). It may, however, reflect between-site differences in the relative importance of nitrification (see above, J.J. Middelburg, personal communication), and likely fluctuates seasonally, which somewhat hampers comparison of our nematode (sampled in May 2004) and organic matter + microphytobenthos (sampled in February 2005) $\delta^{15} \mathrm{~N}$ values.

Data on microphytobenthos (MPB) $\delta^{15} \mathrm{~N}$ are scant. Heavy MPB-signatures have been reported from the mesohaline part of the Schelde estuary in winter (Riera et al., 2000). Other, indirect estimates, have been based on the nitrogen isotopic signatures of known microalgal grazers (Rossi et al., 2004). In winter 2005, MPB $\delta^{15} \mathrm{~N}$ at our study sites was typically depleted by $\sim 2$ ppt relative to bulk sedimentary organic matter, and did not exhibit among-site variability (Table 2 ).

\section{Nematode trophic level}

The dual isotope abundances of Praeacanthonchus punctatus, Daptonema sp., Metachromadora remanei and Chromadoridae spp. are consistent with diatoms as their principal carbon source, even though the $\delta^{13} \mathrm{C}$ of Daptonema and Chromadoridae are comparatively a little depleted, suggesting some contribution of settled SPOM to their diet. In the mouth-morphology based feeding type classification by Wieser (1953), Daptonema sp. is a non-selective deposit-feeder, while many Chromadoridae and $P$. punctatus are epistrate-feeders and Metachromadora is an omnivore-predator. The food of epistrate-feeders mainly consists of microalgae, while deposit-feeders may ingest a variety of particles selected by size and shape, in the case of Daptonema often including diatoms (Nehring, 1992a,b; Moens \& Vincx, 1997). Observations of living nematodes, however, have shown that Metachromadora feeds like an epistrate-feeder, while $P$. punctatus is capable of swallowing entire (algal) cells much like a depositfeeder does (T. Moens, unpublished results). Indeed, the $\delta^{15} \mathrm{~N}$ of Metachromadora invalidates its classification as a predator. The predominant genus among 'Chromadoridae' in our sample was Ptycholaimellus, the diatom-feeding behaviour of which is well-documented (Nehring, 1992a; Moens \& Vincx, 1997). The $\delta^{15} \mathrm{~N}$ in these primary consumers is at the higher end, though still in the range, of values reported for macrobenthic primary consumers in other estuaries (e.g. Deegan \& Garrit, 1997; Riera et al., 2000), but considerably lower than in a more upstream location in the Schelde estuary (Riera et al., 2000), illustrating substantial spatial and/or temporal variability in estuarine PON $\delta^{15} \mathrm{~N}$.

Taking an average trophic-level increase in $\delta^{15} \mathrm{~N}$ of 3.4 (Vander Zanden \& Rasmussen, 2001; Post, 2002), the within-site range of $\delta^{15} \mathrm{~N}$ (3.6 ppt in Station 1 to $6.3 \mathrm{ppt}$ in Station 3) spans one to two trophic steps. While the carbon isotope abundances of Enoploides longispiculosus, Adoncholaimus fuscus and Enoplus brevis are similar to those of the above diatom grazers, their nitrogen signatures are significantly enriched, confirming their presumed predatory ecology. The predatory ecology of Enoploides longispiculosus is well-documented: it preys on nematodes, ciliates and perhaps other meio- to microsized benthic organisms and may even control prey biomass and community structure (Moens et al., 2000; Hamels et al., 2001; Gallucci et al., in press). However, in an in situ experiment with pulsed labelling of the microphytobenthos with $\mathrm{NaH}^{13} \mathrm{CO}_{3}$, it also assimilated microphytobenthic carbon at a rate similar to that of diatom grazers (Middelburg et al., 2000), a result difficult to explain from a mainly predatory feeding ecology.

Adoncholaimus fuscus, like other oncholaimids, is capable of catching nematode prey, but additional feeding strategies have been suggested (see Moens \& Vincx, 1997 for review). Our current stable isotope data, however, place A. fuscus at the same trophic level as E. longispiculosus and above that of diatom grazers, suggesting that predation and/or scavenging constitute its predominant trophic strategies.

The feeding ecology of Enoplus brevis from a Wadden Sea salt marsh has been studied on the basis of gut content analysis, indicating a shift from an omnivorous to a more exclusively predacious feeding strategy upon maturation (Hellwig-Armonies et al., 1991). Our $\delta^{15} \mathrm{~N}$ confirm a predacious ecology of adults of this species. The single sample of juvenile (mainly third-stage juveniles) E. brevis collected at Station 1, however, does not support the idea that juveniles depend less on predation. The $\delta^{15} \mathrm{~N}$ of $E$. brevis were also typically $2 \mathrm{ppt}$ higher than values of Enoploides longispiculosus and A. fuscus, suggesting differences in resources and/or in resource assimilation and allocation in the tissues (Gannes et al., 1997). Alternatively, Enoplus brevis may have a wider prey range than the other species studied here, perhaps including other predatory nematodes.

Species of the genus Sphaerolaimus have been observed to feed on other nematodes (Moens \& Vincx, 1997). This is confirmed by the $\delta^{15} \mathrm{~N}$ of the salt marsh Sphaerolaimus, but 
not by that of the Station 3 sample. In the absence of replication, this deviant value has to be carefully interpreted. Similarly, the single result for Ascolaimus elongatus should not be overinterpreted; however, if confirmed, it suggests that a predacious feeding ecology may be more widespread than expected from current mouth-morphology and-limited!-observation-based evidence. Ascolaimus elongatus has an unarmed mouth and is generally considered a (non-selective) deposit-feeder (Wieser, 1953). Therefore, if predacious, prey may rather consist of protozoans than of other meiobenthos, and ingestion is likely through swallowing of entire prey. The high $\delta^{15} \mathrm{~N}$ of $A$. elongatus is particularly puzzling since it is a frequent prey of Enoploides longispiculosus (Moens \& Gallucci, unpublished observations).

In any case, it is clear from our data that nematodes cannot be confined to a single trophic level. Although this is fairly well-known, its implications have not always been recognized in dual isotope studies reporting data on a nematode community level. Because predacious nematodes can be quite abundant and are typically rather large and heavy-built, their biomass contribution can sometimes dominate whole-community samples and isotopic signatures and will consequently yield higher $\delta^{15} \mathrm{~N}$ than expected of primary consumers.

\section{Methodological considerations}

While the biomass requirements for EA-IRMS are still problematic when trying to include meiobenthic organisms in dual isotope studies on foodweb structure, dedicated sampling and analytical procedures may allow inclusion of prominent (in terms of density, individual biomass or both) members of the meiobenthos. As few as five (adult) individuals were required of the large nematode species Adoncholaimus fuscus and Enoplus brevis, ten Sphaerolaimus sp. and 20 Enoploides longispiculosus. For more average-sized nematodes, we pooled 80 (for P.punctatus and Metachromadora remanei) to 300 (for Chromadoridae) individuals, corresponding to $\mathrm{N}$-values in the range of $5-15 \mu \mathrm{g}$, assuming a nematode $\mathrm{C} / \mathrm{N}$-ratio of $\approx 6$. Hence, when species diversity is not too high and average individual biomass is not very low, dual isotope analysis at species/genus level is feasible provided sufficiently large samples are collected and sorted. Specific modifications to conventional EA-IRMS systems may reduce carbon and nitrogen requirements to 2 and $\geqslant 1 \mu \mathrm{g}$, respectively (Carman \& Fry, 2002). However, because of the time-consuming sorting effort, routine inclusion of meiobenthos, with proper replication, in dual isotope studies is still not evident.

A correct interpretation of nematode trophic level depends on accurate knowledge of the trophic shift for stable isotope ratios. Here we have adopted average values as proposed, among others, by Vander Zanden \& Rasmussen (2001) and Post (2002). However, trophic shift varies among different organisms as well as among tissues within an organism (McCutchan Jr et al., 2003), and no such data are available for nematodes.

Finally, diet and even trophic position of consumers may be temporally variable. The present dataset refers to a single moment in time - although the comparatively high $\delta^{15} \mathrm{~N}$ of $A$. fuscus and E. longispiculosus have been confirmed in other seasons (T. Moens, unpublished data) - during which microphytobenthos production was high. More elaborate sampling, covering seasonal variability in isotopic signatures of both consumers and all relevant organic matter sources, will be necessary to improve the conclusiveness of the results presented here.

Financial support was obtained from the Flemish Fund for Scientific Research (FWO) (Projects G.0118.02 and 31521704). T.M. and S.B. are postdoctoral fellows with this fund. Dr Victor Chepurnov skilfully isolated the microphytobenthos from our samples. Christine Van der Heyden is acknowledged for her help in preparing the figures.

\section{REFERENCES}

Bouma, T.J., Stapel, J., Heiden, J. van der, Koutstaal, B., Soelen, J. van \& IJzerloo, L. van, 2002. Relative importance of macrophyte leaves for nitrogen uptake from flood water in tidal salt marshes. Marine Ecology Progress Series, 240, 93-104.

Carman, K.R. \& Fry, B., 2002. Small-sample methods for $\delta^{13} \mathrm{C}$ and $\delta^{15} \mathrm{~N}$ analysis of the diets of marsh meiofaunal species using natural-abundance and tracer-addition isotope techniques. Marine Ecology Progress Series, 240, 85-92.

Couch, C.A., 1989. Carbon and nitrogen stable isotopes of meiobenthos and their food resources. Estuarine, Coastal and Shelf Science, 28, 433-441.

Coull, B.C., 1999. Role of meiofauna in estuarine soft-bottom habitats. Australian fournal of Ecology, 24, 327-343.

Deegan, L.A. \& Garritt, R.H., 1997. Evidence for spatial variability in estuarine food webs. Marine Ecology Progress Series, 147, $31-47$.

Ferris, H., Venette, R.C. \& Lau, S.S., 1997. Population energetics of bacterial-feeding nematodes: carbon and nitrogen budgets. Soil Biology and Biochemistry, 29, 1183-1194.

Gallucci, F., Steyaert, M. \& Moens, T., in press. Can field distributions of marine predacious nematodes be explained by sediment constraints on their foraging success? Marine Ecology Progress Series.

Gannes, L.Z., O’Brien, D.M. \& Rio, G.M. del, 1997. Stable isotopes in animal ecology: assumptions, caveats, and a call for more laboratory experiments. Ecology, 78, 1271-1276.

Hamels, I., Moens, T., Muylaert, K. \& Vyverman, W., 2001. Trophic interactions between ciliates and nematodes from an intertidal flat. Aquatic Microbial Ecology, 26, 61-72.

Hellings, L., Dehairs, F., Tackx, M., Keppens, E. \& Baeyens, W., 1999. Origin and fate of organic carbon in the freshwater part of the Scheldt Estuary as traced by stable carbon isotope composition. Biogeochemistry, 47, 167-186.

Hellwig-Armonies, M., Armonies, W. \& Lorenzen, S., 1991. The diet of Enoplus brevis (Nematoda) in a supralittoral salt marsh of the North Sea. Helgoländer Meeresuntersuchungen, 45, 357-372.

Herman, P.M.J., Middelburg, J.J., Widdows, J., Lucas, C.H. \& Heip, C.H.R., 2000. Stable isotopes as trophic tracers: combining field sampling and manipulative labelling of food resources for macrobenthos. Marine Ecology Progress Series, 204, 79-92.

Kuipers, B.R., Wilde, P.A.W.J. de \& Creutzberg, F., 1981. Energy flow in a tidal flat ecosystem. Marine Ecology Progress Series, 5, 215-221.

Mariotti, A., Lancelot, C. \& Billen, G., 1984. Natural isotopic composition of nitrogen as a tracer of origin for suspended organic matter in the Scheldt estuary. Geochimica et Cosmochimica Acta, 48, 549-555.

McGutchan Jr, J.H., Lewis, W.M., Kendall, G. \& McGrath, C.C., 2003. Variation in trophic shift for stable isotope ratios of carbon, nitrogen, and sulfur. Oikos, 102, 378-390.

Middelburg, J.J., Barranguet, C., Boschker, H.T.S., Herman, P.M.J., Moens, T. \& Heip, G.H.R., 2000. The fate of intertidal microphytobenthos carbon. An in situ ${ }^{13} \mathrm{C}$ labelling study. Limnology and Oceanography, 45, 1224-1234. 
Middelburg, J.J. \& Nieuwenhuize, J., 1998. Carbon and nitrogen stable isotopes in suspended matter and sediments from the Schelde Estuary. Marine Chemistry, 60, 217-225.

Middelburg, J.J., Nieuwenhuize, J., Lubberts, R.K. \& Plassche, O. van de, 1997. Organic carbon isotope systematics of coastal marshes. Estuarine, Coastal and Shelf Science, 45, 681-687.

Moens, T., Herman, P.M.J., Verbeeck, L., Steyaert, M. \& Vincx, M., 2000. Predation rates and prey selectivity in two predacious estuarine nematode species. Marine Ecology Progress Series, 205, 185-193.

Moens, T., Luyten, C., Middelburg, J.J., Herman, P.M.J. \& Vincx, M., 2002. Tracing organic matter sources of estuarine tidal flat nematodes with stable carbon isotopes. Marine Ecology Progress Series, 234, 127-137.

Moens, T. \& Vincx, M., 1997. Observations on the feeding ecology of estuarine nematodes. Fournal of the Marine Biological Association of the United Kingdom, 77, 211-227.

Nehring, S., 1992a. Die Vegetarier unter den freilebenden Nematoden. 1. Die Aufwuchsfresser. Mikrokosmos, 81, 135-140.

Nehring, S., 1992b. Die Vegetarier unter den freilebenden Nematoden. 2. Die Depositfresser. Mikrokosmos, 81, 260-266.

Post, D.M., 2002. Using stable isotopes to estimate trophic position: models, methods and assumptions. Ecology, 83, 703-718.

Riera, P. \& Hubas, C., 2003. Trophic ecology of nematodes from various microhabitats of the Roscoff Aber Bay (France): importance of stranded macroalgae evidenced through $\delta^{13} \mathrm{C}$ and $\delta^{15}$ N. Marine Ecology Progress Series, 260, 151-159.

Riera, P., Richard, P., Grémare, A. \& Blanchard, G., 1996. Food source of intertidal nematodes in the Bay of Marennes-Oléron (France), as determined by dual stable isotope analysis. Marine Ecology Progress Series, 142, 303-309.
Riera, P., Stal, L.J. \& Nieuwenhuize, J., 2000. Heavy $\delta^{15} \mathrm{~N}$ in intertidal benthic algae and invertebrates in the Scheldt Estuary (The Netherlands): effect of river nitrogen inputs. Estuarine, Coastal and Shelf Science, 51, 365-372.

Riera, P., Stal, L.J., Nieuwenhuize, J., Richard, P., Blanchard, G. \& Gentil, F., 1999. Determination of food sources for benthic invertebrates in a salt marsh (Aiguillon Bay, France) by carbon and nitrogen stable isotopes: importance of locally produced sources. Marine Ecology Progress Series, 187, 301-307.

Rossi, F., Herman, P.M.J. \& Middelburg, J.J., 2004. Interspecific and intraspecific variation of $\delta^{13} \mathrm{C}$ and $\delta^{15} \mathrm{~N}$ in deposit- and suspension-feeding bivalves (Macoma balthica and Cerastoderma edule): evidence of ontogenetic changes in feeding mode of Macoma balthica. Limnology and Oceanography, 49, 408-414.

Somerfield, P., Warwick, R.M. \& Moens, T., 2005. Chapter 6. Meiofauna techniques. In Methods for the study of marine benthos, 3rd edn (ed. A. Eleftheriou and A. McIntyre), pp. 229-272. Oxford: Blackwell Science Ltd.

Vander Zanden, M.J. \& Rasmussen, J.B., 2001. Variation in $\delta^{15} \mathrm{~N}$ and $\delta^{13} \mathrm{C}$ trophic fractionation: implications for aquatic food web studies. Limnology and Oceanography, 46, 2061-2066.

Wieser, W., 1953. Die Beziehung zwishen Mundhöhlengestalt, Ernährungsweise und Vorkommen bei freilebenden marinen Nematoden. Arkiv für Zoologie, 4, 439-484.

Submitted 25 April 2005. Accepted 5 August 2005. 